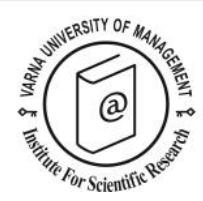

\title{
Digital evolution in tourism marketing channels: Greek tourism industry and Online Travel Agencies
}

\author{
Alexios-Patapios Kontis ${ }^{1 *}$ and Sofoklis Skoultsos ${ }^{2}$
}

\footnotetext{
${ }^{1}$ Department of Tourism Economics and Management - University of the Aegean, 8, Michalon str., Chios, 82132, Greece, E-mail: apkontis@aegean.gr

${ }^{2}$ Department of Tourism Economics and Management - University of the Aegean, Greece
}

${ }^{*}$ Corresponding author

\begin{abstract}
Many unexpected challenges not only for tourism businesses but also for travellers emerged when current shifts in economic, technological, social, and political factors led to a sudden and quick growth of e-intermediaries. Although it was anticipated that the Internet would open new opportunities in the tourism industry, especially as regards more choices and a closer cooperation between consumers and suppliers, this, in fact, is not the case. The appearance of e-intermediaries, but mainly their consolidation and strengthening have led to a series of major rearrangements in the tourist sector. Online distribution channels have changed the existing traditional marketing structures of tourism (e.g. travel agencies and tour operators) but have also had a catalytic effect on the composition of the hospitality sector (e.g. hotels and Airbnb rentals). It is essential for tourism professionals to be aware of new opportunities and threats within tourism distribution channels so that they will be able to remain competitive and successful. This paper examines the hoteliers' opinions on recent changes in tourism distribution in the digital era.
\end{abstract}

Key words: Tourism, Marketing Channels, Online Travel Agencies (OTAs)

Citation: Kontis, A.-P. and Skoultsos, S. (2022). Digital evolution in tourism marketing channels: Greek tourism industry and Online Travel Agencies. European Journal of Tourism Research 30, 3004. 


\section{Introduction}

Various factors based on society and economy have revealed distribution channels as a competitive advantage. As a result, there is an increased need regarding their exploration, understanding and exploitation (Pearce, 2010). Researchers have stated that, in various businesses, competition has changed its focal point (Coughlan, Anderson, Stern \& El-Ansary 2006, Cooper \& Lewis 2001). Specifically, the focal point has changed from quality in production to trade and distribution of qualitative products and services to the customer.

During the last decade, the tourism sector has altered in various ways mainly because of the intangible nature of its services (Kotler, Bowen \& Makens, 2005). Specifically, sharing services and digital evolution in general, has transformed distribution channels in the tourism industry (Gretzel, 2016, Berne, GarciaGonzzales \& Mugica, 2012, Kontis, Skoultsos, Kyriakaki \& Marmara 2018). The latter has led to a complex new context and network of the main tourism distribution channels, which has resulted in a greater complexity because of the appearance of online social networks and online review sites (Zaman, Botti, \& Thanh, 2016, Fountoulaki, Leue \& Jung, 2015). Additionally, new business models of sharing economy platforms and peer-to-peer models have been established (Pappas, 2017, Skoultsos, Kontis \& Sarantakou, 2017) enhancing the interaction between members of tourism service distribution channels (Fountoulaki, Leue \& Jung, 2015, Stankov, Lazic, \& Dragicevic, 2010). These new models have substituted the traditional business models as they can provide opportunities for trade, exchange, rental and sharing services. As a result, newly emerging markets are very competitive to the traditional business models, which provokes a debatable issue.

The importance of distribution channels arises from certain circumstances and changes in the level of competition in the hotel industry. It has been stated that a common practice in the hotel industry is to develop multi-channel strategies to increase the potential of dominating competitors due to a better market coverage (Mei, 2014, Pearce, Tan \& Schott, 2004, Stuart, Pearce \& Weaver, 2005). In addition to the above, various researchers argue that in contemporary hotel industry there are new and innovative channels which have transformed the practices of management and administration to a much more complicated procedure (Katsoni, 2016, Kavoura \& Katsoni, 2013, Zhang, Song \& Huang, 2009, Ivanov, 2008, Pearce \& Taniguchi, 2008).

The management of distribution channels relies on important decision-making on a regular basis and should follow the business goals set by each organization (Kontis \& Lagos, 2016). The viability of an organization is affected by the appropriateness of these decisions as well as their accuracy and validity. It is widely accepted that a good hotel management highlights the important role of its decisions regarding the multi-channel marketing. On the other hand, there are marketing managers who make respective decisions with the use of previous experience and their own professional insight. This practice is obviously related to the evaluation criteria used for the selection of distribution channels. (Kontis, 2014). Kracht and Wang (2010: 737) point out that an adequate understanding of the evolution and transformation of tourism distribution channels is a prerequisite for their effective utilization by tourism professionals.

Tourism distribution operates in a certain way that affects business models and relative strategies from the supply-side, together with the alternative options for the consumer (demand-side) (Pearce, Tan \& Schott, 2004). Undoubtedly, Information and Communication Technologies (ICTs) have evolved rapidly and as a result the distribution processes in the tourism industry have been respectively affected and changed (Berné, Gómez-Campillo \& Orive, 2015, Fouskas, Kitsios, Vlachopoulou, Tsiavos, 2018). Specifically, instead of technological development reducing the levels of intermediaries between the 
producer and the final consumer, as expected, more intricate and complex distribution channels have been created. The relations of interdependence and cooperation among members of tourism channels have altered and strengthened the position of some channel members in relation to others (Kracht \& Wang, 2010). Some factors, such as the power of negotiation and the influence on contributing channel members have altered, with the result that tourism factors will not be able to foresee their own role within the channels in the future. The purpose of this paper is to re-examine issues relating to how evolution of Information and Communication Technologies (ICTs) influences tourism distribution channels from the perspective of tourism suppliers (hotels). It also focuses on the criteria they use to make decisions about their distribution strategies, as the quality of these decisions is directly related to the course of business over time (Kontis \& Lagos, 2016, Kontis, 2014).

\section{Literature Review}

Coughlan, Anderson, Stern \& El-Ansary (2006: 2) argue that "marketing channels is a set of interdependent organizations involved in the process of making a product or service available for use or consumption”. Additionally, marketing channels do not only aim at offering the right product or service at the right place, quantity, quality, and price, but they continuously increase demand as they add extra value for the user by creating form, possession, time, and place utilities (Fletcher, Fyall, Gilbert, \& Wanhill, 2017, Cabiddu, Lui, Piccoli, 2013).

The term 'marketing channels' is closely related to 'distribution channels' which includes all the necessary procedures for the products or services to be offered to the final consumer (Gartner \& Bachri, 1994). It must be stated that intermediaries are the main connection and exist between consumer and producer. Specifically, intermediaries can be described as "any corporate third party or organization between producer and final consumer that facilitates purchases, the transfer or title of the buyer and sales revenue to the producer" (Middleton \& Clarke, 2001: 293). The term includes retailers, wholesalers, inbound and outbound operators etc. In other words, distribution channels can also be described as a network of interdependent entities that co-exist to support the trade procedures (Rosenbloom, Larsen \& Brent, 2004). It must be highlighted that the goal of distribution channels is the maximization of benefits for their participants. This should always be the main goal, considering the priorities and goals of independent channel partners. This balance is necessary to avoid "partner asymmetries" in the distribution channel system (Harrigan, 1988). Although increasing competition should lead to an increasing need for long term balanced partnerships between channel members, in many cases, members playing leading roles attempt to exert excessive influence on the other members of the channel with the ulterior motive of deriving self-benefit. A central approach in literature on distribution channels focuses on the "power-influence approach", which endeavours to explain leader effectiveness in the source and amount of power available to leaders based on not only reward but also coercive, referent, legitimate, and expert power (Coughlan, Anderson, Stern \& El-Ansary 2006, Lai, 2007). Literature pertaining to distribution channels reveals that conflict results when the behaviour of one channel member disturbs another channel partner to achieve their goals (Coughlan, Anderson, Stern \& El-Ansary 2006, Zhuang, Xi \& Tsang, 2010). This phenomenon is widespread in many sectors where the partner who has direct contact with the end consumer, undertakes a leading role and dictates the conditions of cooperation in the distribution channel. Technological developments have revolutionized business processes on marketing services and modified the relationships within the tourism value chains (Romero \& Tejada, 2020, Sarantopoulos, Gretzel, 2016, Katsoni, Geitona, 2014).

Due to relevant literature on distribution channels, the concept of influence has been widely studied. On the other hand, limited research that focuses on the tourism industry has been conducted and there is still a wide range of issues that need to be examined. This paper aims to reveal the role of Online 
Travel Agents (OTAs) and distribution channels, in general, within the Greek hotel industry. Specifically, the paper evaluates the characteristics and influences of online and offline channels, based on primary research in the Greek market, combined with relative secondary data from the respective European hotel industry. Additionally, it monitors the selection criteria of distribution channels used by hotel marketing managers.

\section{Tourism Distribution Channels in the European Hotel Industry}

Tour operators, as tourism intermediaries, are one of the major factors in the tourism industry (Morrison, Lehto, \& Day, 2018, Kotler, Bowen, Makens, \& Baloglu, 2016). According to the result of the European Hotel Distribution Survey (2020) conducted by HOTREC based on responses from over 2.800 hoteliers, between 2013 and 2019 the dependence of hotels on tourism intermediaries has increased by $11.6 \%(2013=39.4 \%-2019=51.0 \%)$, so, more than one out of two overnights was generated through the channels of intermediaries. Booking trends show that online platforms are gaining more and more control over the European hotel distribution market, as in 2019, when they served the $32.9 \%$ of total market, increasing their contribution by $10.7 \%$ over the same period $(2013=\mathbf{2 2 . 2} \%-2019=32.9 \%)$. In parallel to the rise of the share of OTAs in hotels bookings, the share of direct bookings decreased by $12.1 \%(2013=57.6 \%-2019=45.5 \%)$. During the same period, in the Greek market, the share of direct bookings decreased to $10.1 \%$ from $54.7 \%$ (2013) to $44.6 \%$ (2019) and the total dependence on intermediaries increased by $9.4 \%(2013=42.4 \%-2019=51.8 \%)$. Hotels in Greece are less dependent on online intermediaries $(2019=22.1 \%)$ than the rest of Europe $(2019=32.9 \%)$, but at the same time some traditional Tour Operator and Travel Agencies hold 29.7\% of the Greek market, presenting significant deviation (11.6\%) in relation to the corresponding European Market $(2019=18.1 \%)$. The tight embrace of Greek hoteliers to the traditional intermediaries of tourism (Buhalis, 200o) has lasted for years and is due to the structural traits of the tourist development model of the country $(3 \mathrm{~S})$. The Greek hotels have long experienced the positive and negative effects of tourism intermediaries (Alegre \& Sard, 2015, Sigala, 2008) in relation to the respective European ones (Bywater, 2001). If the above trends continue in the same direction, it is obvious that the position of the European hoteliers will soon deteriorate further, significantly reducing their independence and the ability to react in the distribution of their tourist products.

Table 1. Market Shares of Tourism Distribution Channels (\%) Weighted Samples






\begin{tabular}{|c|c|c|c|c|c|c|c|c|c|c|c|c|}
\hline \multirow{4}{*}{$\begin{array}{l}\text { Online Booking Agency (OTA) } \\
\text { Global Distributions Systems (GDS) }\end{array}$} & \multicolumn{4}{|c|}{ Europe } & \multirow{2}{*}{\multicolumn{2}{|c|}{\begin{tabular}{|c|} 
Europe \\
$2019-2017$
\end{tabular}}} & \multicolumn{4}{|c|}{ Greece } & \multirow{2}{*}{\multicolumn{2}{|c|}{\begin{tabular}{|c|} 
Greece \\
$2019-2017$
\end{tabular}}} \\
\hline & \multicolumn{2}{|c|}{2019} & \multicolumn{2}{|c|}{2013} & & & & 019 & & 013 & & \\
\hline & $29 \cdot 9$ & & 19.7 & & 10.2 & & 20.4 & & 16.3 & & +4.1 & \\
\hline & 2.4 & 32.9 & 2.0 & 22.2 & 0.3 & 10.7 & 0.9 & 22.1 & 0.5 & 18.1 & 0.4 & +4.0 \\
\hline Social Media Channels & 0.7 & & 0.4 & & 0.2 & & 0.8 & & 1.3 & & -0.5 & \\
\hline Other Distribution Channels & 2.7 & 2.7 & 1.5 & 1.5 & 1.2 & 1.2 & 3.0 & 3.0 & 1.5 & 1.5 & +1.5 & +1.5 \\
\hline
\end{tabular}

Source: Schegg R. (2020), "European Hotel Distribution Study: Results for the Reference Year 2019", Hotrec

Recently, there has been considerable discussion on the issue of disintermediation in the tourism industry considering changes in the technological and business environment. However, the result of a previous research may not show an accurate picture of the present situation since industry practitioners often react to and perceive disintermediation differently (Law, Leung, Lo, Leung \& Nang Fong, 2015). Disintermediation would supposedly result in a more direct contact between consumers and hoteliers, but in fact, the entrance of new powerful e-intermediaries is the new reality. Findings show a steady increase in the share of online platforms in hotel bookings, whereas there is a notable decline in the hotels' own distribution channels. This has resulted in growing dependency on OTAs.

A percentage of $91 \%$ of the European tourism market which moves through online distribution channels is in the hands of three Online Tour Operators (OTAs). Particularly, Booking.com is the dominant player with a share of $68.4 \%$ followed by $H R S$ with $16.3 \%$ and Expedia Group with $7.2 \%$. The growing share of OTAs, which already holds $1 / 3$ of the total tourism market, has led to the emergence of oligopolistic conditions in the European tourism market. In countries such as Greece, where the dominance of tourism intermediaries is even stronger and room for further expansion of online intermediates exists, the hospitality sector is expected to feel the pressure of leaders in the field of tourism distribution. There is a fear among hoteliers that they will be ousted from all control of bookings, as OTAs acquire absolute power in the overall tourism market.

Table 2. Market shares of major OTAs in Europe (2013-2019)

\begin{tabular}{llll}
\hline & \multicolumn{3}{c}{ Europe } \\
\cline { 2 - 4 } & $\mathbf{2 0 1 3}$ & $\mathbf{2 0 1 9}$ & DELTA \\
\hline Booking Holdings (Booking.com, Agoda) & 60.0 & 68.4 & +8.4 \\
Expedia Group (Expedia, Hotels.com, eBookers etc) & 14.5 & 7.2 & -7.3 \\
HRS (HRS, Hotel,de, Tiscover) & 16.6 & 16.3 & -0.3 \\
Total & 91.1 & 91.9 & +0.8 \\
\hline
\end{tabular}

Source: Schegg R. (2020), “European Hotel Distribution Study: Results for the Reference Year 2019”, Hotrec

Current socio-economic and technological trends shape and determine conditions for the distribution of tourism services. This and the considerable dependency of hotels on OTAs dictate their perception of the factors of distribution and their ability to shape efficient long- and short-term tourism distribution strategies. The vital role of distribution channels for the achievement of business pursuits makes the management of the former a difficult task, particularly in a multi-channel business sector such as tourism. What makes having an efficient administration in the operation of distribution channels hard is both financial and non-financial factors. The financial indicators chiefly consider past performance and are unable to predict future developments. This results in the administrators' inability to properly make rational decisions concerning the future. Quantitative factors provide reliable data based on existing results while qualitative factors can allow a relatively accurate picture of potential future performance. Decisions made by administration can be improved by combining the objective 
and effective use of a wide range of quantitative and qualitative data. Factors such as sales price, turnover, channel cost but also reputation, commitment, dependency, are crucial for effective tourism distribution strategies (Kontis, 2014).

\section{Methodology and Sampling}

Data from the Greek hotel industry were collected by implementing quantitative primary research with a structured on-line questionnaire. The latter included 18 close-ended and scale questions because they are credible in measuring people's perceptions (Oppenheim, 1992). The questionnaire was delivered electronically with the support of local hotel associations and focused on 4 main categories: a) market shares per overnight stay of each channel (direct and indirect), b) market shares of OTAs (i.e. Booking.com, Expedia), c) relationship between hotels and OTAs, d) characteristics of hotel samples.

Regarding hotel sample, researchers implemented purposive (Babbie, 2011) and convenience sampling (Christou, 1999). The survey was conducted from August to November 2018 and the respondents were hotel managers and hotel marketing managers. All the categories of hotels were included in the survey to check possible variations in answers. Finally, 236 valid responses were gathered and were appropriate for analysis. Table 3 presents the main characteristics of the samples. Statistical Package for Social Science (SPSS 26) was used as the appropriate software for statistical analysis and a combination of descriptive, arithmetic, and graphic statistical methods were used. Non-parametric tests were conducted using Kruskal-Wallis test to investigate the existence of statistical significance between the different types of hotels.

Table 3. Research Sample (\%)

\begin{tabular}{|c|c|c|c|c|c|c|}
\hline \multirow{3}{*}{ Star category } & $5^{*}$ & $4^{*}$ & $3^{*}$ & $2^{*}$ & $1^{*}$ & Total \\
\hline & 28 & 55 & 99 & & & \multirow{8}{*}{$\begin{array}{l}236 \\
100 \%\end{array}$} \\
\hline & $11.9 \%$ & $23.3 \%$ & $41.9 \%$ & $20.8 \%$ & $2.1 \%$ & \\
\hline \multirow{3}{*}{ Hotel Size (rooms) } & $<20$ & $21-50$ & 51-100 & $>101$ & & \\
\hline & 8 & 151 & 54 & 23 & & \\
\hline & $3.4 \%$ & $64.0 \%$ & $22.9 \%$ & $9.7 \%$ & & \\
\hline \multirow{3}{*}{ Seasonality } & all year & winter & \multicolumn{2}{|l|}{ summer } & & \\
\hline & 133 & 27 & 76 & & & \\
\hline & $56.4 \%$ & $11.4 \%$ & $32.2 \%$ & & & \\
\hline
\end{tabular}

\section{Results}

Marketing channels are inter-organizational networks where members work together to achieve supraorganizational goals in competition with other channels and reach their performance targets in competition with other companies within and outside the network. In these networks, the power balance is largely explained by the network structure itself as well as by the interaction with the market structure which influence the market power of each individual in the channel.

Hoteliers can easily enter the arena of digital marketing for direct communication with their customers and online sales. However, this process can be extremely difficult producing weak results for the majority of hoteliers, since they are in competition with powerful online intermediaries of tourism. The secondary data from the HOTREC pan-European study clearly show that the control of tourism distribution is being passed very fast to e-intermediary businesses that exploit the ITC technologies in the most efficient way. The above contribute substantially to shaping the views of hoteliers on their relationship with Online Tour Operators. 
Underlining some aspects of the relations with OTAs, a percentage of $95.4 \%$ of Greek hoteliers states that the registration to OTAs is unavoidable. They also accept that the viability of their hotels depends mainly on OTAs (80.9\%), but at the same time argue that the commission taken by OTAs is very high compared to what they are offered in return (90.3\%). The above facts are corroborated by Inversini and Masiero (2014) who have proved that it is essential for hoteliers to use online intermediaries such as Booking.com in order to both acquire new customers as well as retain existing ones.

The overriding majority of hoteliers (84.3\%) argue that the disputes between OTAs and hoteliers are not solved fairly for both parties and $66.6 \%$ of hoteliers feel pressed by OTAs to accept terms and conditions of platforms that they do not want, with only $6.3 \%$ who disagree. Although it is clear that hoteliers feel that they are at a disadvantage in relation to OTAs, in fact they recognize the vital role of OTAs accepting that they could not avoid cooperating with OTAs (52.5\%), and only $38.2 \%$ of hoteliers state that they are attempting to break free from them. The above is evidence that the dependence of hotels mainly on electronic distributors, is particularly large in the marketing of their services. As a result, despite numbers of complaints, they are unable to terminate this co-operation as they are not sufficiently developed to provide alternatives for the distribution of their services.

Table 4. Hotels and OTAs relationship

\begin{tabular}{|c|c|c|c|c|c|}
\hline & $\begin{array}{l}\text { Strongly } \\
\text { Disagree }\end{array}$ & Disagree & $\begin{array}{l}\text { Neither } \\
\text { Agree } \\
\text { Nor } \\
\text { disagree }\end{array}$ & Agree & $\begin{array}{l}\text { Strongly } \\
\text { Agree }\end{array}$ \\
\hline Registration with OTAs is unavoidable & $0.4 \%$ & $1.3 \%$ & $3.0 \%$ & $17.4 \%$ & $78.0 \%$ \\
\hline $\begin{array}{l}\text { Viability of hotels depends mainly on } \\
\text { OTAs }\end{array}$ & $2.1 \%$ & $4 \cdot 7 \%$ & $12.3 \%$ & $39.8 \%$ & $41.1 \%$ \\
\hline $\begin{array}{l}\text { Commission of the OTAs is very high } \\
\text { compared to what they offer }\end{array}$ & $0.0 \%$ & $0.0 \%$ & $9 \cdot 7 \%$ & $38.6 \%$ & $51.7 \%$ \\
\hline $\begin{array}{l}\text { Pressure to accept platforms' terms } \\
\text { and conditions that I do not want }\end{array}$ & $2.5 \%$ & $3.8 \%$ & $27.1 \%$ & $29.7 \%$ & $36.9 \%$ \\
\hline $\begin{array}{l}\text { Disputes between OTAs and hoteliers } \\
\text { are solved fairly for both parties }\end{array}$ & $53 \cdot 4 \%$ & $30.9 \%$ & $8.9 \%$ & $5 \cdot 9 \%$ & $0.8 \%$ \\
\hline Attempting to break free from OTAs & $7.6 \%$ & $12.3 \%$ & $41.9 \%$ & $17 \cdot 4 \%$ & $20.8 \%$ \\
\hline $\begin{array}{l}\text { I wish to break free from OTAs but } \\
\text { cannot }\end{array}$ & $26.7 \%$ & $25.8 \%$ & $21.6 \%$ & $15 \cdot 3 \%$ & $10.6 \%$ \\
\hline
\end{tabular}

Regarding the hoteliers' opinions on OTAs, a Kruskal-Wallis test was undertaken in order to examine differences in responses related to hotel category, hotel size and seasonality. The results indicated that 5 out of 7 variables demonstrate differences ( $p>0.05$ ) in the respondents' perception of the relationships between hoteliers and OTAs, comparing hotel categories, hotel size and seasonality ( $\mathrm{p}>0.05)$. Exceptions are found only in "Pressure to accept platforms' terms and conditions that I do not want" related to seasonality $(\mathrm{p}=0.069)$ and "Attempting to break free from OTAs" related to Star Category $(\mathrm{p}=0.053)$ and Seasonality $(\mathrm{p}=0.206)$ (results presented at Table 5). 
Table 5. Hotels and OTAs relationship-Kruskal-Wallis test

\begin{tabular}{|c|c|c|c|c|}
\hline \multirow[b]{2}{*}{ Variables } & \multirow[b]{2}{*}{ Mean } & \multicolumn{3}{|l|}{ p-value* } \\
\hline & & $\begin{array}{l}\text { Star } \\
\text { Category }\end{array}$ & $\begin{array}{l}\text { Hotel } \\
\text { Size } \\
\text { (rooms) } \\
\end{array}$ & Seasonality \\
\hline Registration with OTAs is unavoidable & 4.71 & $\mathbf{0 . 0 0 0}$ & 0.000 & $\mathbf{0 . 0 0 0}$ \\
\hline Viability of hotels depends mainly on OTAs & 4.13 & 0.000 & 0.001 & 0.002 \\
\hline $\begin{array}{l}\text { Commission of the OTAs is very high } \\
\text { compared to what they offer }\end{array}$ & 4.42 & 0.001 & 0.000 & 0.047 \\
\hline $\begin{array}{l}\text { Pressure to accept platforms' terms and } \\
\text { conditions that I do not want }\end{array}$ & $3 \cdot 94$ & 0.000 & 0.000 & 0.069 \\
\hline $\begin{array}{l}\text { Disputes between OTAs and hoteliers are } \\
\text { solved fairly for both parties }\end{array}$ & 1.70 & 0.000 & 0.006 & 0.000 \\
\hline Attempting to break free from OTAs & $3 \cdot 31$ & 0.053 & 0.008 & 0.206 \\
\hline I wish to break free from OTAs but cannot & 2.57 & 0.000 & 0.000 & 0.006 \\
\hline
\end{tabular}

Table 6. Hotels and OTAs relationship per hotel category

\begin{tabular}{|c|c|c|c|c|c|c|}
\hline \multirow[t]{2}{*}{ Variable } & \multicolumn{5}{|c|}{ Mean } & \multirow{2}{*}{$\begin{array}{l}\text { p value } \\
\text { Kruskal - } \\
\text { Wallis }\end{array}$} \\
\hline & $5^{*}$ & $4^{*}$ & $3^{*}$ & $\mathbf{2}^{*}$ & $\mathbf{1}^{*}$ & \\
\hline Registration with OTAs is unavoidable & 4.1 & 4.6 & 4.9 & 5 & 3.8 & 0.000 \\
\hline Viability of hotels depends mainly on OTAs & $3 \cdot 3$ & 3.7 & 4.4 & $4 \cdot 5$ & 5 & 0.000 \\
\hline $\begin{array}{l}\text { Commission of the OTAs is very high } \\
\text { compared to what they offer }\end{array}$ & 4.1 & $4 \cdot 3$ & $4 \cdot 5$ & $4 \cdot 7$ & 4.8 & 0.001 \\
\hline $\begin{array}{l}\text { Pressure to accept platforms' terms and } \\
\text { conditions that I do not want }\end{array}$ & 3.0 & $3 \cdot 3$ & 4.1 & 4.9 & 4.8 & 0.000 \\
\hline $\begin{array}{l}\text { Disputes between OTAs and hoteliers are } \\
\text { solved fairly for both parties }\end{array}$ & 2.1 & 2.4 & 1.4 & 1.5 & 1.0 & 0.000 \\
\hline Attempting to break free from OTAs & 3.6 & 3.6 & 3.2 & 3.0 & 3.0 & 0.053 \\
\hline I wish to break free from OTAs but cannot & 1.7 & 1.8 & 2.9 & 3.0 & 5 & 0.001 \\
\hline
\end{tabular}

Table 7. Hotels and OTAs relationship per hotel size

\begin{tabular}{|c|c|c|c|c|c|}
\hline \multirow[t]{2}{*}{ Variable } & \multicolumn{4}{|c|}{ Mean } & \multirow{2}{*}{$\begin{array}{l}\text { p value } \\
\text { Kruskal - } \\
\text { Wallis }\end{array}$} \\
\hline & $<\mathbf{2 0}$ & 21-50 & $51-100$ & $>101$ & \\
\hline Registration with OTAs is unavoidable & $4 \cdot 3$ & 4.9 & 4.4 & 4.4 & 0.000 \\
\hline Viability of hotels depends mainly on OTAs & 4.6 & $4 \cdot 3$ & $3 \cdot 9$ & 3.2 & $\mathbf{0 . 0 0 0}$ \\
\hline $\begin{array}{l}\text { Commission of the OTAs is very high } \\
\text { compared to what they offer }\end{array}$ & 4.8 & $4 \cdot 5$ & $4 \cdot 3$ & 4 & 0.000 \\
\hline $\begin{array}{l}\text { Pressure to accept platforms' terms and } \\
\text { conditions that I do not want }\end{array}$ & $4 \cdot 9$ & 4.1 & $3 \cdot 5$ & $3 \cdot 5$ & $\mathbf{0 . 0 0 0}$ \\
\hline $\begin{array}{l}\text { Disputes between OTAs and hoteliers are } \\
\text { solved fairly for both parties }\end{array}$ & 1.1 & 1.6 & 2 & 2 & 0.006 \\
\hline Attempting to break free from OTAs & 3.1 & 3.2 & 3.6 & $3 \cdot 9$ & 0.008 \\
\hline I wish to break free from OTAs but cannot & 4.1 & 2.9 & 1.9 & 1.7 & o.ooo \\
\hline
\end{tabular}


Table 8. Hotels and OTAs relationship per seasonality

\begin{tabular}{|c|c|c|c|c|}
\hline \multirow[t]{2}{*}{ Variable } & \multicolumn{3}{|c|}{ Mean } & \multirow{2}{*}{$\begin{array}{l}\text { p value } \\
\text { Kruskal } \\
\text {-Wallis }\end{array}$} \\
\hline & All year & Winter & Summer & \\
\hline Registration with OTAs is unavoidable & 4.6 & 4.9 & 4.9 & 0.000 \\
\hline Viability of hotels depends mainly on OTAs & $3 \cdot 9$ & $4 \cdot 3$ & $4 \cdot 4$ & 0.002 \\
\hline $\begin{array}{l}\text { Commission of the OTAs is very high } \\
\text { compared to what they offer }\end{array}$ & $4 \cdot 3$ & $4 \cdot 4$ & $4 \cdot 4$ & $\mathbf{0 . 0 4 7}$ \\
\hline $\begin{array}{l}\text { Pressure to accept platforms' terms and } \\
\text { conditions that I do not want }\end{array}$ & 3.8 & 3.8 & 4.2 & 0.069 \\
\hline $\begin{array}{l}\text { Disputes between OTAs and hoteliers are } \\
\text { solved fairly for both parties }\end{array}$ & 1.9 & 1.3 & 1.5 & 0.000 \\
\hline Attempting to break free from OTAs & $3 \cdot 3$ & 3.1 & $3 \cdot 5$ & 0.206 \\
\hline I wish to break free from OTAs but cannot & 2.4 & 2.9 & 2.8 & 0.006 \\
\hline
\end{tabular}

Tables 6, 7 and 8 present the means for each of the variable that examines the relationship between hotels and OTA's, the highest mean per variable ( $1=$ Total disagree, $5=$ Total Agree) and also the $\mathrm{p}$ value from Kruskal-Wallis test. The data show that hotels that operate only during summer tend to agree fully with each variable (except "Disputes between OTAs and hoteliers are solved fairly for both parties"). As a result, the duration of the working season for the hotels affects their relationship with OTAs. Also, considering tables 6 and 7, the strength of large and luxury hotels is clearly stated as they tend to disagree with most of the variables. On the other hand, smaller hotels tend to agree.

Taking into consideration that the quality of decision making for more efficient tourism distribution strategies is the result of the criteria used by each marketing manager, the kind of such criteria has been examined. According to the findings, in all eight categories that reflect the criteria that are used by hoteliers in order to evaluate their distribution partners, the mean scores are over 4.38 , indicating a relative dynamic of the evaluation criteria used for distribution partners.

Table 9. Evaluation of Criteria for choosing distribution partners by hoteliers (Kruskal- test)

\begin{tabular}{|c|c|c|c|c|c|}
\hline \multirow{2}{*}{\multicolumn{2}{|c|}{ Variables }} & \multirow[b]{2}{*}{ Mean } & \multicolumn{3}{|c|}{ p-value ${ }^{*}$} \\
\hline & & & $\begin{array}{l}\text { Category } \\
\text { of Stars }\end{array}$ & $\begin{array}{l}\text { Hotel Size } \\
\text { (rooms) }\end{array}$ & Seasonality \\
\hline \multirow{4}{*}{ 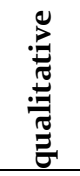 } & Cooperation Commitment & 4.44 & 0.000 & 0.000 & 0.035 \\
\hline & Reputation to customers & 4.38 & o.ooo & 0.000 & 0.036 \\
\hline & Cooperation level & $4 \cdot 51$ & 0.000 & 0.045 & 0.009 \\
\hline & Target Groups Penetration & 4.38 & o.ooo & 0.005 & 0.434 \\
\hline \multirow{4}{*}{ } & Channel Cost/Commission Rate & 4.59 & $\mathbf{0 . 0 0 0}$ & 0.034 & 0.033 \\
\hline & Achieve higher sales prices & $4 \cdot 72$ & 0.029 & 0.092 & 0.410 \\
\hline & Financial Reliability / Trust & 4.65 & 0.040 & 0.187 & 0.044 \\
\hline & Sales / booking volume & 4.71 & 0.000 & 0.079 & 0.037 \\
\hline
\end{tabular}

The results of primary research show that there are strong and significant differences in the criteria (qualitative \& quantitative) in the decision making of distribution partners compared to hotel categories. Moreover, there are significant differences ( $p>.05$ ) in 5 variables (from a total number of 8 ) compared to hotel size and in 6 variables (from a total number of 8) compared to seasonality (Table 9). 
Table 10. Criteria for choosing distribution partners per hotel category

\begin{tabular}{|c|c|c|c|c|c|c|c|}
\hline & & $5^{*}$ & $4^{*}$ & $3^{*}$ & $\mathbf{2}^{*}$ & $1^{*}$ & $\begin{array}{l}\text { p value } \\
\text { Kruskal- } \\
\text { Wallis } \\
\end{array}$ \\
\hline \multirow{4}{*}{ 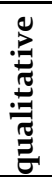 } & Cooperation Commitment & 4.8 & 4.6 & 4.4 & 4.1 & 4.2 & o.ooo \\
\hline & Reputation to customers & $4 \cdot 7$ & $4 \cdot 5$ & $4 \cdot 3$ & 4.2 & 4.2 & o.ooo \\
\hline & Cooperation level & $4 \cdot 7$ & 4.8 & $4 \cdot 3$ & $4 \cdot 5$ & 4.4 & o.ooo \\
\hline & Target Groups Penetration & $4 \cdot 7$ & 4.8 & 4.2 & 4.1 & 4.2 & o.ooo \\
\hline \multirow{4}{*}{ 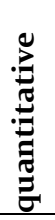 } & $\begin{array}{l}\text { Channel Cost/Commission } \\
\text { Rate }\end{array}$ & $4 \cdot 5$ & 4.2 & 4.7 & 4.8 & 4.8 & o.ooo \\
\hline & Achieve higher sales prices & $4 \cdot 5$ & 4.6 & 4.8 & 4.7 & 4.8 & 0.029 \\
\hline & Financial Reliability / Trust & $4 \cdot 4$ & 4.6 & $4 \cdot 7$ & $4 \cdot 7$ & 4.8 & 0.040 \\
\hline & Sales / booking volume & $4 \cdot 4$ & $4 \cdot 5$ & 4.8 & 4.8 & 5.0 & o.ooo \\
\hline
\end{tabular}

Table 11. Criteria for choosing distribution partners per hotel size (number of beds)

\begin{tabular}{|c|c|c|c|c|c|c|}
\hline & & $<20$ & $21-50$ & $51-100$ & $>101$ & $\begin{array}{l}\text { p value } \\
\text { Kruskal- } \\
\text { Wallis }\end{array}$ \\
\hline \multirow{4}{*}{ 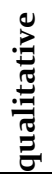 } & Cooperation Commitment & 4.0 & $4 \cdot 4$ & 4.6 & $4 \cdot 9$ & $\mathbf{0 . 0 0 0}$ \\
\hline & Reputation to customers & $4 \cdot 3$ & $4 \cdot 3$ & 4.6 & $4 \cdot 7$ & o.ooo \\
\hline & Cooperation level & $4 \cdot 4$ & $4 \cdot 5$ & 4.6 & $4 \cdot 7$ & 0.045 \\
\hline & Target Groups Penetration & 4.0 & $4 \cdot 3$ & $4 \cdot 5$ & $4 \cdot 7$ & 0.005 \\
\hline \multirow{4}{*}{ } & Channel Cost/Commission Rate & 4.9 & 4.6 & 4.4 & 4.5 & 0.034 \\
\hline & Achieve higher sales prices & 4.8 & 4.8 & 4.7 & $4 \cdot 5$ & 0.092 \\
\hline & Financial Reliability / Trust & 4.6 & $4 \cdot 7$ & 4.6 & $4 \cdot 5$ & 0.187 \\
\hline & Sales / booking volume & 4.9 & 4.8 & 4.6 & 4.6 & 0.079 \\
\hline
\end{tabular}

Table 12. Criteria for choosing distribution partners per Seasonality

\begin{tabular}{|c|c|c|c|c|c|}
\hline & & All year & Winter & Summer & $\begin{array}{l}\text { p value } \\
\text { Kruskal- } \\
\text { Wallis }\end{array}$ \\
\hline \multirow{4}{*}{ 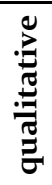 } & Cooperation Commitment & $4 \cdot 5$ & $4 \cdot 3$ & $4 \cdot 4$ & 0.035 \\
\hline & Reputation to customers & $4 \cdot 5$ & $4 \cdot 3$ & $4 \cdot 3$ & 0.036 \\
\hline & Cooperation level & 4.6 & 4.4 & 4.4 & 0.009 \\
\hline & Target Groups Penetration & 4.4 & 4.4 & $4 \cdot 3$ & 0.434 \\
\hline \multirow{4}{*}{ 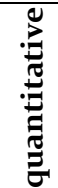 } & Channel Cost/Commission Rate & $4 \cdot 5$ & 4.6 & $4 \cdot 7$ & 0.033 \\
\hline & Achieve higher sales prices & $4 \cdot 7$ & 4.8 & 4.8 & 0.410 \\
\hline & Financial Reliability / Trust & 4.6 & 4.8 & 4.7 & 0.044 \\
\hline & Sales / booking volume & 4.6 & 4.8 & 4.8 & $\mathbf{0 . 0 3 7}$ \\
\hline
\end{tabular}

Data regarding the criteria for choosing distribution partners per hotel category, hotel size and seasonality are presented in Tables 10, 11 and 12 respectively. Data show that superior category hotels tend to use more qualitative criteria such as cooperation commitment, reputation with customers, cooperation level and target-group penetration, when making decisions. However, lower category hotels 
use quantitative factors such as channel cost/commission rate, achievement of higher sales prices, financial reliability/trust and sales/booking volume. Specifically, according to hotel category all the above variables are statistically significant due to Kruskal-Wallis test (last column on table 10). Additionally, statistical significance is reported in all qualitative variables (criteria) based on hotel size (last column on table 11) and in the majority of the criteria based on seasonality. These findings clearly state that qualitative variables such as cooperation commitment, reputation to customers, cooperation level and target groups penetration" are taken into account mostly by four- and five-star hotels. Accordingly, as expected, this conclusion is further applied to hotel size and seasonality that are clearly affected by hotel category because 4- and 5-star hotels are usually large hotels and many of them operate during all year.

\section{Discussion}

Marketing and distribution channels in tourism constitute the 'umbilical cord' that connects businesses with markets. Business decisions related to distribution strategies of their products and services may determine their course to success or failure (Kotler, Bowen \& Makens 2005: 451). Although the components of products or/and services are those which significantly determine their success in markets, it is now clear that the procedures and terms of their placing on the market by producers to purchasers play an equally considerable role. 'These procedures require the establishment of relationships not only with the final customers but also with the main suppliers and resellers of a company's supply chain' (Armstrong and Kotler 2009: 446). These relationships present several peculiarities in tourism due to the insubstantial nature of services and the fragmented productive structure of tourism, where there is a great number of small businesses (Zhang, Song к $\alpha$ ı Huang). Additionally, the consolidation of e-intermediaries in tourism are influencing the relational dynamics by changing the balance of power between the various actors in the tourism industry (Berné, GarciaGonzàlez, Garcìa-Uceda \& Mùgica, 2015, Bastakis, Buhalis \& Butler, 2004), at the expense of tourism suppliers, which is proven by the primary and secondary data of this article.

Research results show that there is a correlation of category, size and seasonality of hotels regarding the way hoteliers perceive their relationships with OTAs (Table 5). Thus, the hotel product and probably the quality and effectiveness of hotel management mechanisms seem to influence their relationships with OTAs. Specifically, lower category hotel $\left(3^{*}-1^{*}\right)$ corporate members consider the recording and availability of their hotel rooms through OTAs inevitable, as the viability of their businesses mainly depends on them (table 6). The recognition of the high degree of dependence on OTAs forces them to accept cooperation terms which they do not desire. Instead, corporate members of higher category accommodation $\left(5^{*}-4^{*}\right)$ diverge from the views above, probably because some data, such as the thoroughness of the tourist product they offer and the awareness of brand, allow the development of alternative marketing strategies (e.g., Loyalty program) and distribution strategies (real time booking over hotels website). The adoption of multi-channel distribution strategies by higher category hotels allows the sharing of sale risk among several alternative marketing channels (direct and indirect), thus reducing the dependence degree on individual OTAs (Kontis, 2014, Pearce \& Taniguchi, 2008). This situation makes them feel that they negotiate with their channel collaborators on equal terms (table 6). Finally, the 'Commission of the OTAs is very high compared to what they offer' variable reaches high rates for all accommodation categories. However, the rates of lower hotel categories are even higher, which requires a deeper study so as for the reasons to be determined (e.g., a feeling of intense pressure, payment of higher commissions, etc.)

Analysing the relationships between hoteliers and OTAs regarding the size of hotels, it arises that corporate members of smaller size accommodation (<20 rooms) appear to feel more dependent on 
OTAs in comparison to their colleagues of bigger hotels (Table 7). More specifically, they claim that OTAs' commission cost is particularly high compared to what they offer them, whereas at the same time they feel weak to react to their imposition of heavy terms and conditions by OTAs. Corporate members of smaller size accommodation have a reduced negotiation power, since their business viability depends on OTAs. Small hotel businesses 'suffer' from a lack of technical knowledge on management, strategic planning and marketing issues (Simons \& Bouwman, 2004, Bastakis, Buhalis \& Butler, 2004). This weakness has probably received a greater extent in the existing environment, characterised by an increasing competition, constant and rapid developments and a technological progress of businesses and the economy. Time is among the main factors which affects the production and trade of tourist products, due to the special traits of the nature of services (e.g., perishability). This special aspect of tourism seems to influence the results of the current research, as hotel owners who operate in one season (summer or winter), having a limited operation span, state that their relationship with OTAs receives greater pressure compared to accommodation of yearly operation (table 8). Thus, hotel owners, who operate only in summer months serving a great tourist flow mainly from abroad, claim to have a high dependence on OTAs and small margins to react to or negotiate cooperation terms with other members of the distribution channel.

Tourism businesses that wish to handle the adverse conditions formed, regardless of category, size and seasonality, will have to determine the sources of their weaknesses which render them vulnerable to their commercial partners. By investing in the improvement of administrative operation and by adopting modern marketing strategies and practices for the whole range of a hotel operation, it is possible for such businesses to enhance their negotiating position and reduce their dependence degree on tourism intermediaries.

The constantly increasing competition and the fast deterioration of complexity in the business environment raise the need for valid and effective decision making in first line business areas, such as Marketing Management. Despite the fact that marketing administrations of the hotel sector identify the vital role of their decisions in forming multi-channel marketing mixes, relative decisions are made in a vague environment. They are also based on empirical knowledge and professional intuition, without the expected scientific documentation (Kontis, 2014). The effectiveness evaluation of marketing channels regarding material goods has received attention by the research community since very early (Brendel, 1951, Pegram, 1965, Stern \& El-Ansary, 1992, Medcof, 1997), without, however, the respective research being conducted in tourism. Yilmaz (2006) suggested a useful but general frame of measuring the competency of the value chain in tourism, emphasizing the lack of development in systems measuring efficiency in the tourist sector (Yilmaz \& Bititci, 2006). However, projects that followed determined a framework of quality and quantity factors used by those in charge of marketing to assess tourism distribution channels (Kontis 2014, Kontis \& Lagos 2015, Kontis, Lymperopoulos \& Lagos, 2013).

In the present research, the investigation of the criteria used to select partners in tourism distribution channels shows that there are strong and significant differences in these (qualitative and quantitative) criteria, in relation to both category and size of hotels (table 9). Specifically, higher category hotels $\left(5^{*}\right.$ $4^{*}$ ) tend to unitize more qualitative criteria such as "Cooperation Commitment", "Reputation to customers", "Cooperation level" and "Target Groups Penetration", whereas lower category hotels $\left(3^{*}-1^{*}\right)$ focus on the exploitation of quantitative criteria such as "Achieve higher sales prices", "Channel Cost/Commission Rate", "Sales/booking volume" and "Financial Reliability/Trust" (table 10). According to table 11, a similar picture is presented in the analysis based on hotel size, where hotel owners with a high availability of beds state their preference in the qualitative (non-financial) criteria to select channel partners, while smaller hotel owners prefer quantitative (financial) ones. 
The exploitation of quantitative data is more connected with simple and easy to apply systems measuring efficiency which provide evidence about the past, whereas focus on qualitative (nonfinancial) data is based on the belief that they provide information on the medium to long term efficiency of businesses. This allows initiatives to be taken which lead to the improvement of the economic efficiency of businesses, too (Said, Hassab Elnaby \& Wier 2003, Olve, Roy \& Wetter 1999, Ittner \& Larcker 2003). Future research could focus on the investigation of the correlation of existing findings with the structural elements of the administrative skill of different category hotels.

Finally, hotels which operate throughout the year prefer to assess marketing channels on the basis of such criteria as "Cooperation level", "Cooperation Commitment" and "Reputation to customers", while seasonal hotels adopt more 'occasional' approaches, showing a preference to cooperate with distribution channels that will achieve a high efficiency level in relation to the "Sales/booking volume" $\kappa \alpha \iota$ "Achieve higher sales prices" variables.

\section{Limitations \& Future research}

The results should be considered along with the following limitations. First, the sample of $1^{*}$ hotels is limited. Also, the current research used a list of variables derived from previous research which should be enhanced in future. Qualitative methods for gathering primary data such as focus groups, in-depth interviews etc. can reveal other variables to be checked regarding the relationship between hotels and OTAs. Moreover, spatial and destination characteristics should be considered during future research in order to examine possible variations in responses between different kinds of destinations. Additionally, future research will have to focus on reasoning and a deeper understanding of the findings that have arisen in the particular research as well as seeking strategies and practices to cope with them.

\section{Conclusions}

Prior to the development of the Internet in the tourism sector, travel agencies and tour operators were the only choice for hoteliers. Consequently, it was thought that the development of Information and Communication Technologies (ICTs) would offer an ideal opportunity for disintermediation in tourism. Digital evolution in the tourism industry has meant a change in the position of power of the people involved. This process has led to changes in the contribution of the members of distribution channels to the final tourism product, as they have been affected to a different extent. An improved position of power entails an increase in responsibility in the value chain.

Obviously, with the entrance of new powerful intermediaries a 're-intermediation' takes place following technological changes and new characteristics of business environment. This 're-intermediation' means that powerful new intermediaries enter the industry and that disintermediated ones may also re-enter. A variety of tools are available to consumers through the Internet and mobile technology allowing them to search for and purchase services directly from the suppliers. As a result, e-intermediaries in tourism distribution channels are in the powerful position of exploiting this situation, thus harming that of the suppliers. So the power is now in the hands of the intermediaries who use new technology rather than in the hands of the suppliers.

The above is evidence of how necessary it is for researchers to focus on tourism distribution channels, particularly to achieve a more effective management which would contribute to a better multi-channel marketing mix. This would fulfil the business objectives in the era of the new digital evolution. Specifically, research must focus not only on relations between suppliers and distributors in the tourism industry but go further and seek elements which configure these relations. The latter are obviously influenced by internal management expertise in the making of decisions on marketing strategies. 
Although, Hotel managers understand the importance of efficient distribution channels, their actual decisions in shaping of marketing channel strategies do not yield the expected results. As a result, understanding how tourism distribution functions is important for hoteliers to use effective marketing strategies and policies.

The business and technological environment is constantly changing. Therefore, it is inevitable that research findings reflect the situation as it is today but not as it will be in the immediate future, since it is impossible to predict how channel members will react to or act on the issue of disintermediation.

\section{References}

Alegre, J., M. Sard (2015). When demand drops and prices rise: Tourist packages in the Balearic Islands during the economic crisis. Tourism Management 46, 375-385. Doi: 10.1016/j.tourman.2014.07.016

Babbie, E. (2011). Introduction to Social Research (in Greek). Athens: Kritiki. ISBN:9789602187500

Bastakis, C., D. Buhalis, R. Butler (2004). The perception of small and medium sized tourism accommodation providers on the impacts of the tour operators' power in the Eastern Mediterranean. Tourism Management 25(2), 151-170. DOI:10.1016/So261-5177(03)ooo98-o

Berné, C., M. Garcia-Gonzàlez, M.E. Garcì-Uceda, J.M. Mùgica (2015). The effect of ICT on relationship enhancement and performance in tourism Channel. Tourism Management 48, 188-198. Doi: 10.1016/j.tourman.2014.04.012

Berne, C., M. Garcia-Gonzzales, J. Mugica (2012). How ICT shifts the power balance of tourism distribution channels. Tourism Management 33(1), 205-214. Doi: 10.1016/j.tourman.2011.02.004

Berné, C., M. Gómez-Campillo, V. Orive (2015). Tourism distribution system and Information and Communication Technologies (ICT) development: Comparing data of 2008 and 2012. Modern Economy 6, 145-152. DOI:10.4236/me.2015.62012

Brendel, L. (1951). Where to find and How to choose your Industrial Distributors. Sales Management 15, 128-132

Buhalis, D. (2000). Relationships in the distribution channel of tourism: Conflicts between hoteliers and tour operators in the Mediterranean region. International Journal of Hospitality $\mathcal{E}$ Tourism Administration 1(1), 113-139. DOI:10.1300/J149v01no1_07

Bywater, M. (2001). Who owns whom in the European travel and distribution industry. In Buhalis, D., E. Laws (eds) (2001) Tourism Distribution Channels: Practices, issues and transformations. London: Continuum International Publishing Group, 151-171. ISBN:0826454704

Cabiddu, F., T.W. Lui, G. Piccoli (2013). Managing Value Co-creation in the tourism industry. Annals of Tourism Research 42, 86-107. Doi: 10.1016/j.annals.2013.01.001

Christou, E. (1999). Tourism Market Research (in Greek), Athens: Interbooks. ISBN:9789603900467

Cooper, C., J. Lewis (2001). Transformation and trends in the tourism industry: Implications for distribution channels. In Buhalis, D., E. Laws (eds) (2006) Tourism Distribution Channels: Practices, Issues and Transformations. London: Continuum, 315-332. ISBN:0826454704

Coughlan, A., E. Anderson, L. Stern, A. El-Ansary (2013). Marketing Channels, 7th ed. New Jersey: Pearson Prentice Hall. ISBN:1292023503

Fletcher, J., A. Fyall, D. Gilbert, S. Wanhill (2017). Tourism: Principles and practice (6th ed). Harlow: Pearson. ISBN:9781292172392

Fountoulaki P., M.C. Leue, T. Jung (2015). Distribution Channels for Travel and Tourism: The Case of Crete, In Tussyadiah I., A. Inversini (eds) (2015), Information and Communication Technologies in Tourism, Vienna: Springer International Publishing, 667-68o. DOI:10.1007/978-3-319-14343-9_48

Fouskas, K., F. Kitsios, M. Vlachopoulou, V. Tsiavos (2018). Challenges for digital expansion to international markets. Global Fashion Management Conference, 2018. 370-382. DOI:10.15444/GMC2018.03.08.06 
Gartner, W.C., T. Bachri (1994). Tour operators' role in the tourism distribution system: An Indonesian case study. Journal of International Consumer Marketing 6(3), 161-179. Doi: 10.130o/Jo46vo6no3_o9

Gretzel, U. (2016). The New Technologies Tsunami in the Hotel Industry. In Ivanova, M., S. Ivanov, V. Magnini, (eds.) (2016). Routledge Handbook of Hotel Chain Management. London: Routledge, 490497. DOI:10.4324/9781315752532.ch42

Harrigan, K.R. (1988). Partner asymmetries. In Contractor, J., P. Lorange (eds.) (1988) Cooperative Strategies in International Business. Lexington: Lexington Books, 205-226.

Inversini, A., L. Masiero (2014). Selling rooms online: The use of social media and online travel agents. International Journal of Contemporary Hospitality Management 26(2), 272-292. DOI:10.1108/IJCHM03-2013-0140

Ittner, C., D. Larcker (1998). Innovations in Performance Measurement: Trends and Research Implications. Journal of Management Accounting Research 10, 205-238

Ivanov, S. (2008). Conceptual marketing framework for online hotel reservation system design. Tourism Today 8, 7-32. DOI:10.2139/ssrn.1296040

Katsoni, V. (2016). An Investigation of the Tourism Distribution Channels in the VFR Segment. Academica Turistica 9(1), 19-29.

Kavoura, A., V. Katsoni, (2013). From e-business to c-commerce: Collaboration and network creation for an e-marketing tourism strategy. Tourismos 8(3), 113-128. ISSN:1790-8418

Konstantopoulos, K., Th. Stavrinoudis, M. Doumi (2008). The interdependency of Business Beliefs and Management Attitudes in the Greek tourism market. Studies in Regional Urban Planning 11(c), 61-73.

Kontis A.P., C. Lymperopoulos, D. Lagos (2013). Decision Factors for the Evaluation of the Tourist Marketing Channels for Attica's $5 *$ and $4{ }^{*}$ Hotels". Paper presented at the 5 th International Scientific Conference - Tourism Trends \& Advances in the 21st Century, $30^{\text {th }}$ May $-2^{\text {nd }}$ June 2013, Rhodes

Kontis, A.P., S. Skoultos, A. Kyriakaki, A. Marmara (2018). Reexamining tourism experience during the new era of peer-to-peer business models: The demand's perspective, In Christou, E., K. Alexandris, A. Fotiadis (eds), TOURMAN 2018 Conference Proceedings "In search of excellence in tourism, travel E hospitality". 449-504.

Kontis, A.P. (2014). Factors in multichannel marketing mix configuration for urban hotels: optimisation framework in decision making, based on the data envelopment analysis. (PhD Thesis in Greek), Chios: University of the Aegean.

Kontis, A.P., D. Lagos (2016). Chapter 12: Data driven marketing decision making: An application of DEA in tourism marketing channels. In Rontos, K., F. Jose (eds.) (2016) Modeling and New Trends on Tourism: A Contribute for Social and Economic Development. New York: Nova Publishers, 195-214. ISBN:978-1-63485-920-2

Kotler, P., J. Bowen, J. Makens (2005). Marketing and Hospitality for Tourism, 4th Edition. New Jersey: Prentice Hall International

Kotler, P., J. Bowen, J. Makens (2014). Marketing and Hospitality for Tourism, 6th ed. New Jersey: Prentice Hall International. ISBN:9780132784023

Kotler, P., J. Bowen, J. Makens, S. Baloglu (2016). Marketing for Hospitality and Tourism (7th ed). Harlow: Pearson. ISBN:9780134141695

Kracht, J., Y. Wang (2010). Examining the tourism distribution channel: Evolution and transformation. International Journal of Contemporary Hospitality Management 22(5), 736-757. DOI:10.1108/09596111011053837

Lai, C.S. (2007). The effects of influence strategies on dealer satisfaction and performance in Taiwan's motor industry. Industrial Marketing Management 36(4), 239-252. Doi: 10.1016/j.indmarman.2005.08.015

Law, R., R. Leung, A. Lo, D. Leung, L.H. Nang Fong (2015). Distribution channel in hospitality and tourism: Revisiting disintermediation from the perspectives of hotels and travel agencies. 
International Journal of Contemporary Hospitality Management 27(3), 431-452. DOI:10.1108/IJCHM11-2013-0498

Medcof, J. (1997). Why too many alliances end in divorce. Long Range Planning 30, 718-732. DOI:10.1016/Soo24-6301(97)00050-2

Mei, X. (2014). Revisiting the role of incoming tour operators (ITOs): Initial findings from Eastern Norway. European Journal of Tourism Research 8, 148-156. https://ejtr.vumk.eu/index.php/about/article/view/155

Middleton, V., A. Fyall, M. Morgan, A. Ranchhod (2009). Marketing in Travel and Tourism, 4th ed. Oxford: Butterworth-Heinemann. ISBN:9780750686938

Morrison, A.M., X.Y. Lehto, J.G. Day (2018). The Tourism System (8th ed.). Dubuque: Kendall Hunt Publishing. ISBN:978-1465299253

Olve, N., L. Roy, M. Wetter, (1999). Performance Drivers: A Practical Guide to using the Balanced Scorecard. New York: John Wiley \& Sons. ISBN:978-0-471-49542-o

Oppenheim, A. N., (1992). Questionnaires Design, Interviewing and Attitude Measurement, London: Continuum. ISBN:978-0826451767

Pappas, N. (2017). The complexity of purchasing intentions in peer-to-peer accommodation. International Journal of Contemporary Hospitality Management 29(9), 2302-2321. Doi: 10.1108/IJCHM-08-2016-0429

Pearce, D. G., (2009). Channel design for effective tourism distribution strategies. Journal of Travel $\mathcal{E}$ Tourism Marketing 26(5-6), 507-521, DOI:10.1080/10548400903163046

Pearce, D. G., (2010). Chapter 8: Tourism distribution: a review and strategic research agenda. In Pearce, D., R.W. Butler (eds.) (2010). Tourism Research: A 20-20 Vision. Oxford: Goodfellow Publishing, 94110. ISBN:978-1-906884-10-9

Pearce, D. G., M. Taniguchi (2008). Channel performance in multi-channel tourism distribution systems. Journal of Travel Research 46(3), 256-267. DOI:10.1177/0047287507308321

Pearce, D., R. Tan, C. Schott (2004). Tourism distribution channels in Wellington, New Zealand. International Journal of Tourism Research 6(6), 397-410. DOI:10.1002/jtr.503

Pegram, R.M. (1965). Selecting and evaluating distributors, NY: The conference board, Business Policy Study 16(2), 21-91

Romero, I., P. Tejada, (2020). Tourism intermediaries and innovation in the hotel industry, Current Issues in Tourism 23(5), 641-653. DOI:10.1080/13683500.2019.1572717

Rosenbloom, B., T. Larsen, S. Brent (2004). The effectiveness of upstream influence attempts in high and low context export marketing channels. Journal of Marketing Channels 11(4), 3-19. DOI:10.1300/Jo49v11no4_02

Said, A., E. Hassab, W. Benson (2003). An empirical investigation of the performance consequences of non-financial measures. Journal of Management Accounting Research 15(1), 193-224. DOI:10.2308/jmar.2003.15.1.193

Sarantopoulos, I., V. Katsoni, M. Geitona (2014). Medical tourism and the role of e-medical tourism intermediaries in Greece. Tourismos 9(2), 129-145. ISSN:1790-8418

Schegg, R. (2020). European Hotel Distribution Study: Results for the Reference Year 2019, Brussels: Hotrec. https://www.hotrec.eu/european-hotel-distribution-study-2020/

Sigala, M. (2008). A supply chain management approach for investigating the role of tour operators on sustainable tourism: The case of TUI. Journal of Cleaner Production 16(15), 1589-1599. Doi: 10.1016/j.jclepro.2008.04.021

Simons, L., H. Bouwman (2004). Designing a channel mix. International Journal of Internet Marketing and Advertising 1(3), 229-250. DOI:10.1504/IJIMA.2004.005016 
Skoultsos, S., A.P. Kontis, E. Sarantakou (2017). Conceptualization of changes in tourism industry's distribution channels: The case of peer-to-peer $\left(\mathrm{P}_{2} \mathrm{P}\right)$ business models and sharing economy platforms. Journal of Tourism Research 16, 292-303. ISSN:2241-7931

Stankov, U., L. Lazic, V. Dragicevic (2010). The extent of use of basic Facebook user-generated content by the national tourism organizations in Europe. European Journal of Tourism Research 3(2), 105-113. https://ejtr.vumk.eu/index.php/about/article/view/51

Stern, L., A. El-Ansary (1992). Marketing Channels, 4th Edition. New Jersey: Prentice Hall. ISBN: 0135537363

Stuart, P., D. Pearce, A. Weaver (2005). Tourism distribution channels in peripheral regions: The case of Southland, New Zealand. Tourism Geographies 7(3), 235-256. DOI:10.1080/14616680500164740

Yilmaz, Y. (2006). Tourism Companies need change in the Business Performance Measurement Systems. 23rd EuroChrie Conference, $26^{\text {th }}-28^{\text {th }}$ October 2006, Paris

Yllmaz, Y., U.S. Bititci (2006). Performance measurement in tourism: A value chain model. International Journal of Contemporary Hospitality Management 18(4), 341-349. Doi: 10.1108/o9596110610665348

Zaman, M., L. Botti, T.V. Thanh (2016). Weight of criteria in hotel selection: An empirical illustration based on TripAdvisor criteria. European Journal of Tourism Research 13, 132-138. https://ejtr.vumk.eu/index.php/about/article/view/236

Zhang, X., H. Song, G. Huang (2009). Tourism supply chain management: A new research agenda. Tourism Management 30(3), 345-358. Doi: 10.1016/j.tourman.2008.12.010

Zhuang, G., Y. Xi, A. Tsang (2010). Power, conflict, and cooperation: The impact of Guanxi in Chinese marketing channels. Industrial Marketing Management 39(1), 137-149. Doi: 10.1016/j.indmarman.2008.07.002

Received: 03/09/2019

Accepted: 19/04/2021

Coordinating editors: Maro Vlachopoulou and Konstantinos Fouskas 